ROSCOE ON THE ATMOSPHERE OF DWELLING-HOUSES. 251

XXVI.-Some Chemical Facts respecting the Atmosphere of Dwelling-houses.

By Henry E. Roscoe, B.A., Ph. D.

The following communication contains the results of an investigation carried on for the purpose of supplying chemical data respecting the warming and ventilating of private dwelling-houses, including barracks, under a Commission appointed for that purpose by the General Board of Health.

The atmosphere of a closed inhabited space is rendered unfit for continued respiration long before the greater part of the oxygen has disappeared. The presence of mere traces of the products of combustion is sufficient to produce an unhealthy atmosphere, even when almost the normal amount of the active constituent is present. It is, therefore, by the quantity of impurities introduced into the air and not by a diminution of the oxygen that we are best able to judge of the capability of such an atmosphere to support healthy animal life. 
The conditions of deterioration which render the supply of fresh air necessary to living animals inhabiting closed spaces, are:

1. The presence of an excessive quantity of the oxides of carbon and other poisonous gases.

2. The presence of either too large or too small a quantity of aqueous vapour dissolved in the air.

3. The presence of organic putrescent bodies, effluvia, proceeding from decomposing animal or vegetable matter.

4. Inconvenient elevation of temperature, arising from the heat of combustion.

The existence of any one of these four sources of deterioration in the air, in which animals dwell for any length of time, is injurious to the health of such animals. In general, however, these four conditions of insalubrity occur together, and an efficient system of ventilation must, thererore, 1st, free the air from the excess of the products of the oxidation of carbon; 2ndly, adjust the proper equilibrium between the air and the dissolved aqueous vapour; 3rdly, carry off completely all putrescent organic matter disseminated through the air; and 4thly, establish an agreeable mean temperature.

In order to determine how we can best diminish the quantity of carbonic acid produced in a closed space by the respiration of animals, and the combustion of illuminating bodies, we must know how much carbonic acid is evolved by the animals inhabiting the spaces under consideration, and by the substances used for illuminating purposes; and also how small a quantity of the oxides of carbon affects the health of such animals. The best experimental data concerning the first of these points we obtain from the researches of Scharling, who determined the amounts of carbonic acid exhaled by various individuals under the normal conditions of pressure, temperature, \&c. Scharling found that the mean quantity of carbonic acid given off by an adult man per hour amounted to 34.8 grammes, or 17.52 litres (1069.2 cubic inches). An indirect method of obtaining the amount of expired carbonic acid from the total volume of respired air and its known percentage of carbonic acid, gives rather a larger number for the quantity of carbonic acid evolved per head per hour, viz., 22.08 litres (1348 cubic inches) (Vierordt, Huchinson). The mean of these two volumes, or 19.8 litres (1208 cubic inches) may, therefore, be taken as representing the maximum quantity of carbonic acid evolved per head per hour. 
The exact determination of the second point is at present impossible, from the absence of any direct experimental facts upon which a conclusion might be based. It is, however, generally admitted, that air containing more than 1 per cent. of carbonic acid is injurious, and that air containing more than 0.5 per cent, is likewise hurtful if breathed for any length of time (Leblanc. Peclét). Reid and Arnott give a much lower limit to the noninjurious effects of this gas; but these statements have not been verified by exact experiment. Hence it is at present premature to say that the smallest increase above the normal amount (4 in 10,000 ) is not productive of harm, and therefore no limit can be fixed at which the carbonic acid becomes innoxious; the object of ventilation in this particular being to diminish the quantity of carbonic acid as much as possible below the limit admitted to be hurtful, without incurring other unpleasant effects arising from draughts, air, or reduction of temperature. It would nevertheless appear impossible, by any system of ventilation, to reduce the quantity of carbonic acid contained in an inhabited closed space to the proportion found in the free atmosphere.

Carbonic oxide acts as a much more violent poison on the animal body than carbonic acid; an atmosphere containing 1 per cent. of the former gas being immediately fatal to animal life, whilst respiration can be continued, although with difficulty, in air containing from 4 to 5 per cent. of the latter gas; hence, every trace of carbonic oxide, arising from a possible entrance of the products of the combustion of heating materials, must be immediately removed.

The average amount of aqueous vapour dissolved in the free atmosphere throughout the year is about 75 per cent. of the saturating quantity (Müller); hence we may conclude that in artificially heated spaces, the proportion of aqueous vapour should not vary much from this amount. This is borne out by practice; for in heating the House of Lords the conditions under which an agreeable atmosphere, as regards aqueous vapour, is found to exist, are when the difference between the wet and dry-bulb thermometers, at a mean temperature of $17.8^{\circ} \mathrm{C}$, is more than $1.7^{\circ} \mathrm{C}$, and less than $5^{\circ} \mathrm{C}$, corresponding to an amount of watery vapour varying from 82 to 55 per cent. on the saturating quantity.

The third cause of deterioration in an inhabited confined atmosphere, viz., the presence of organic putrescent matters, animal effluvia, is one which for the present we are unable to estimate chemically, and, therefore as, cateris paribus, the amount 
of carbonic acid evolved from oxidation of the animal body must be proportional to the quantity of decomposing organic matter, we must, for the present, take the carbonic acid as representing deterioration both from respiration and from putrescent exhalation.

The opinions regarding the quantity of air required for the healthy continuance of respiration are, as has been stated, very various. Upon purely practical and experimental grounds Péclet (Traité de la Chaleur) concludes that each man requires 5 cubic feet per minute. His conclusions are based, lst., upon the amount of air which it was found necessary to admit, in order to exclude all closeness and smell from schools, and 2ndly, upon the amount of air, at the mean atmospheric temperature, and half saturated with aqueous vapour, which became saturated by the moisture given off from the body. The minimum quantity of air which a man should receive per minute, is according to Vierord $t, 2 \frac{1}{2}$ cubic feet; Dr. Reid advises 10 cubic feet, and Dr. Arnott considers 20 cubic feet necessary. From the following experiments in barrack and school-rooms, I have come to the conclusion that 10 cubic feet per minute per head is insufficient to remove all effluvia, and to diminish the carbonic acid to a satisfactory minimum limit, and that probably at least 20 cubic feet per head per minute is necessary to remove completely the organic putrescent matter, at least in the case of soldiers' sleeping-rooms.

The amount of ventilation required in a room of a given size, oceupied by a given number of persons, must naturally partly depend upon the duration of the occupation, although in most cases an equilibrium between the produced and escaping carbonic acid is soon established.

The various sources from which a supply of fresh air is obtained, may be divided into two classes ; ist, natural, or accidental sources, or means of access of air not solely employed for the purpose of ventilation, such as chimneys, windows, walls, doors, \&c.; 2ndly, artificial, or special sources, or means employed for the direct object of increasing the supply of air.

The present incomplete state of the whole subject of ventilation, depends in great measure on the want of precise information on two fundamental points. We have already considered the first of these, viz., when is, and when is not a closed inhabited space unhealthy? to this question no definite answer can be given. The second point upon which our knowledge is equally defective relates to the amount of exchange of air which we obtain from the acci- 
dental sources under all possible conditions. Until we know exactly when an atmosphere is unhealthy, and can determine how much fresh air enters, and deteriorated air issues from our windows, doors, and chimneys, under given circumstances, we cannot expect that the subject of ventilation should assume a definite form.

The determination of the first of these defective points involves a laborious investigation in physiological chemistry; and the full examination of the second point also entails an extended series of determinations, of which the results would be valuable and trustworthy only when the experimental data had increased to a very large amount.

I have been unable, up to the present time, to enter at all fully into this latter most important fundamental question. I have merely made one series of determinations which may serve to show the interesting facts which might be obtained from a more extended experimental enquiry.

\section{Experiment I.}

A quantity of carbonic acid was evolved in a room of 2,560 cubic feet capacity, containing no fire and a closed flue, and all doors (four) and windows (two) were shut. The carbonic acid contained in the inclosed air was then determined at consecutive half-hours. The following are the experimental data:-Temp. of air, $11^{\circ} 1$. Barometric pressure, $0 \cdot 7546^{\mathrm{m}}$.

\begin{tabular}{l|c|c|c|c}
\hline & at $0^{\mathrm{h}} 0^{\prime}$ & at $0^{\mathrm{h}} 30^{\prime}$ & at $1^{\mathrm{h}} 0^{\prime}$ & at $1^{\mathrm{h}} 30^{\prime}$ \\
\hline $\begin{array}{l}\text { Weight of carbonic } \\
\text { acid obtained. }\end{array}$ & $\begin{array}{c}\text { grm. } \\
0.0135\end{array}$ & $\begin{array}{c}\text { grm. } \\
0.0062\end{array}$ & $\begin{array}{c}\text { grm. } \\
0.0058\end{array}$ & $\begin{array}{c}\text { grm. } \\
0.0058\end{array}$ \\
\hline $\begin{array}{l}\text { Volume of water escap- } \\
\text { ing. }\end{array}$ & 1 litre & 1 litre & 1 litre & 1 litre \\
\hline & at $0^{\mathrm{h}} 0^{\prime}$ & at $0^{\mathrm{h}} 30^{\prime}$ & at $1^{\mathrm{h}} 0^{\prime}$ & at $1^{\mathrm{h}} 30^{\prime}$ \\
\hline \\
$\begin{array}{l}\text { Volume of carbonic acid } \\
\text { in } 1000 \text { of air. }\end{array}$ & 7.207 & 3.310 & $3 \cdot 099$ & 3.099 \\
\hline
\end{tabular}


It is thus seen that the carbonic acid diminishes in half an hour from 0.7 to 0.3 per cent. of the total volume of air although all direct ventilation was checked. After the first half-hour the amount of carbonic acid remained constant, possibly from the continued respiration of two persons in the confined atmosphere. The exchange of carbonic acid through close windows, doors, and walls appears from this experiment to be very great.*

In order to form some idea of the amount of gaseous diffusion which takes place through brick and mortar walls, I have determined the quantity of carbonic acid which diffuses through a common brick. For this purpose a brick was cemented with pitch into the end of a box, 3 feet long and 9 inches broad, by $4 \frac{1}{2}$ inches deep. The interior of the box was lined with pitch, and carbonic acid was led into the box by means of two tubes cemented into the sides. After the box had stood for some minutes to allow the gas to diffuse equally throughout the space, a sample of the contained atmosphere was collected, by allowing the air in the box to enter a gas-collecting tube previously filled with mercury. The carbonic acid contained in the samples of air thus collected in consecutive hours was determined eudiometrically. In order to exclude an error, arising from a possible leakage of the box, a second series of analyses were made in the same way, with the exception that the whole brick was covered with a layer of pitch, and thus the leakage determined. The following table gives the result of the analysis.

EXPERIMENT II.

A. Determination of diffusive interchange through brick.

1. Collected directly after filling.

\begin{tabular}{ll|c|c|c|c}
\hline & Vol. & Pressure. & ${ }^{\circ} \mathrm{C}$ & $\begin{array}{c}\text { Vol. at } 0^{\circ} \mathrm{C} \text { and } \\
0.76 \text { pressure. }\end{array}$ \\
\hline Vol. of gas employed &. & $122 \cdot 1$ & 0.7410 & 10.2 & 114.8 \\
After absorption of $\mathrm{CO}^{2}$ & 102.8 & 0.7320 & 10.2 & 95.4 \\
\hline
\end{tabular}

* In confirmation of this fact, I may state that a perfectly analogous result was obtained independently by Professor Pettenk ofe $\mathrm{r}$ in Munich. 
ATMOSPHERE OF DWELLING-FIOUSES.

2. Collected after standing one hour.

\begin{tabular}{ll|r|r|r|r}
\hline Vol. of gas employed & $104 \cdot 3$ & 0.7243 & $10 \cdot 2$ & $95 \cdot 6$ \\
After absorption of $\mathrm{CO}^{2}$ & $89 \cdot 1$ & 0.7196 & $7 \cdot 7$ & 82.0 \\
\hline
\end{tabular}

3. Collected after standing two hours.

\begin{tabular}{lr|r|r|r|r}
\hline Vol. of gas employed & $\cdot$ & 104.3 & 0.7268 & 7.7 & 96.9 \\
After absorption of $\mathrm{CO}^{2}$ &. & 92.5 & 0.7206 & 8.5 & 85.1 \\
\hline
\end{tabular}

B. Control experiment with pitched brick.

1. Collected directly after filling.

\begin{tabular}{l|c|c|c|c}
\hline & Vol. & Pressure. & ${ }^{\circ} \mathrm{C}$ & $\begin{array}{c}\text { Vol. at } 0^{\circ} \mathrm{C} \text { and } \\
0.76 \text { pressure. }\end{array}$ \\
\hline Vol. of gas employed & 92.7 & 0.7053 & 6.6 & 84.0 \\
After absorption of $\mathrm{CO}^{2}$. & 79.5 & 0.6974 & 5.3 & 71.6 \\
\hline
\end{tabular}

2. Collected after standing three hours.

\begin{tabular}{l|c|c|c|c}
\hline Vol. of gas employed & $115 \cdot 6$ & 0.7233 & 6.0 & $107 \cdot 7$ \\
After absorption of $\mathrm{CO}^{2}$. & 101.6 & 0.7235 & $7 \cdot 0$ & 94.3 \\
\hline
\end{tabular}

From experiment A we have,

Sample 1 contained 16.96 per cent. of carbonic acid.
, 2 \% 14.22 , "
" 3 " $12 \cdot 17$ ",$"$,

Hence the loss of carbonic acid in lst hour was $2 \cdot 74$ per cent.

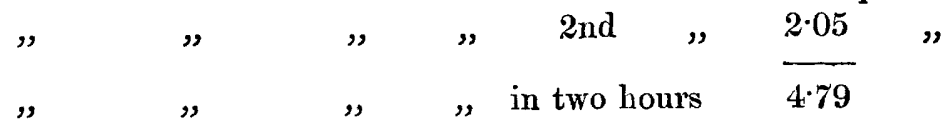

From experiment $B$ we find that in two hours a leakage of 1.54 per cent. of carbonic acid occurred. Hence the amount of carbonic acid which diffused through the brick was in two hours $4 \cdot 79-1 \cdot 54=3 \cdot 25$ per cent. on a total of 16 per cent. of carbonic 
acid. That is, when a closed space contained 16 per cent. of cars bonic acid, more than 3 per cent. escaped through a solid brick in two hours.

The beneficial action of our brick and mortar walls is therefore, not merely confined to taking up or giving off moisture to the air, for they are eminently hygroscopic, but an actual and very large diffusive interchange goes on within the pores of the brick and mortar, so that our walls become a most important aid to ventilation. Of course the kind of surface covering which the walls possess, will materially influence the amount of diffusion which takes place through them, but the well-known unhealthiness of iron or new and damp houses, may probably to some extent be accounted for by the absence of all diffusive interchange through the wet walls. Owing to the impossibility of estimating the animal effluvia in inhabited spaces, the following experiments consist chiefly of carbonic acid determinations, together with estimation of dissolved aqueous vapour, and in one instance a determination of the traces of carbonic oxide and hydrocarbons present in the confined atmosphere.

By means of a large aspirator, a known volume of air $\mathrm{V}$, under a known pressure $P$, and at a known temperature $t$, can be drawn over a system of weighed tubes, alternately filled with pumice-stone stecped in sulphuric acid and potash. The two tubes furthest from the aspirator contained sulphuric acid for the purpose of drying the air, the next two tubes contained hydrate of potash in a soft spongy mass to absorb the carbonic acid, and the next two tubes contained sulphuric acid to retain any moisture taken from the potash. The volume of dry air $V_{1}$ at $0^{\circ}$ and 0.76 , is found from the following equation, in which $\mathrm{p}$ signifies the tension of aqueous vapours at $t^{\circ} \mathrm{C}$.

$$
\mathrm{V}_{1}=\frac{\mathrm{V}(\mathrm{P}-\mathrm{p})}{(1+0 \cdot 00366 \mathrm{t}) 0 \cdot 76}
$$

The volume of carbonic acid at $0^{\circ} \mathrm{C}$. and 0.76 met. is found in cubic centimetres by multiplying the weight of carbonic acid found in grammes by $503 \cdot 27$, the volume in cub. cent. of 1 gramme of carbonic acid at the normal temperature and barometric pressure.

In order to test the accuracy of the method, a determination was made of the carbonic acid contained in the free air of London on a windy day, February $27,1857$. 
Experiment gave the following results :

Experiment III.

Weight of carbonic acid obtained . . 0.0308 grm.

Volume dissolved aqueous vapour 0.2410 "

Atmospheric temperature . . $\quad .8^{\circ} \mathrm{C}$.

Barometric pressure $\quad . \quad$. $0 \cdot 7725^{\mathrm{m}}$

Hence we have :

Volume of air at $0^{\circ}$ and $0 \cdot 76$. . $42 \cdot 28$ litres.

Carbonic acid . , , . . 15.50 cub. cent. or in 10,000 volumes of air 3.7 of carbonic acid.

The amount of carbonic acid found by Saussure (Pogg. Ann. XIX. 391 ) in the free atmosphere at Chambeisy, on the Lake of Geneva, was $3 \cdot 8$ in 10,000 as a mean of 17 experiments.

In order still more fully to test the trustworthiness of the method, I made use in Experiment No. $\mathrm{V}$ of twice as large an absorbing surface-of potash as that previously and subsequently employed. The results of this analysis shows that the whole of the carbonic acid is withdrawn by two potash tubes.

The first carbonic acid determinations in closed inhabited spaces were made at the Wellington Barracks, in the rooms in which the men were sleeping.

\section{Experiment IV.}

Wellington Barracks. House B, room 16. Capacity of room 7,920 cubic feet. Carbonic acid collected after 16 men had occu-

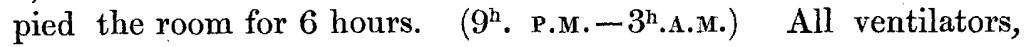
except one over fire-place, closed. Common wide grate; dimensions of chimney 6 feet from floor, 1 foot 4 by 9 inches. All doors and windows shut. Low fire in grate during experiment. Air collected 2 feet 6 inches from floor, at height of men's heads when in bed.

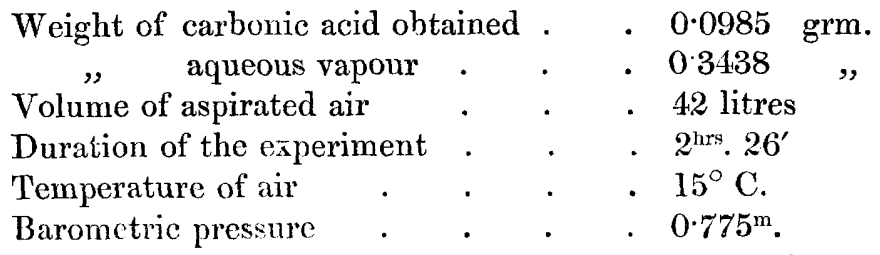


Hence we have :

Volume of air at $0^{\circ} \mathrm{C}$. and 0.76 met . 39.93 litres carbonic acid . . . 49.58 cub. cent. or in 10,000 volumes of air, there are 12.42 volumes of carbonic acid

The amount of aqueous vapour found was 8.61 grammes per cubic metre. From the observations of the wet and dry-bulb thermometer, wet $13^{\circ} 2 \mathrm{C}-$ dry $16^{\circ} 8 \mathrm{C}$; the amount of aqueous vapour is calculated to be 8.9 grammes per cubic metre. Hence the air of the soldiers' sleeping-room contained 66.2 per cent. of the saturaling quantity of aqueous vapour.

Chemical method of determining the amount of ventilation.

We have assumed that a man exhales 0.686 cubic feet of carbonic acid per hour. Hence 16 men will exhale 65.86 cubic feet in 6 hours. We now require to know with what quantity of air must this 65.86 cubic feet of carbonic acid be mixed, so that the percentage of this gas should amount to $0 \cdot 1212$, that is, the quantity found in the barrack-room.

As the free atmosphere contains carbonic acid, we must add more air than we should need were it free from that gas.

If $\mathrm{V}$ represent the volume of pure air which must be added, and $\mathbf{A}$ the fraction which the impurity in the air $(0 \cdot 04)$ is of the limit of impurity in the mixture $(0 \cdot 1242)$, the volumes of air $\left(V_{1}\right)$ which must be added, is found from the expression.

$$
\mathrm{V}_{\mathrm{l}}=\mathrm{V}+\mathrm{Va}+\mathrm{Va}^{2}+\ldots \mathrm{Va}^{\mathrm{n}}
$$

The three first terms of this series are all that need be considered.

In this way it is found that in order to reduce 65.86 cubic feet of carbonic acid to 0.1242 of the total bulk, we require 76,600 cubic feet of air. That is, in 6 hours 76,600 cubic feet of air pass through the room and carry off 0.1242 per cent. of its bulk of carbonic acid. This gives to each man a volume of 13.3 cubic feet per minute, a quantity insufficient to remove completely all animal effluvia.

\section{Physical method of determining the amount of ventilation.}

The quantity of air issuing from any chimney can be calculated, when the mean temperature and the dimensions of the chimney are known.

Temp. of outer air $9^{\circ} \mathrm{C}$.

Mean temp. of chimney $31^{\circ} \mathrm{C}$. 
Height of chimney 57 feet.

Area of chimney-pot 60 square inches.

From these data a volume of 35 cubic feet of air is found to issue from the chimney per minute.

From this determination it would seem that only a portion of the deteriorated air is carried off by the chimney draught, the larger proportion escaping by the other accidental sources of ventilation, viz., windows, doors, and walls

\section{Experiment V.}

Wellington Barracks. Conditions in every respect the same as in the previous experiment. Double the usual number of potashtubes were employed.

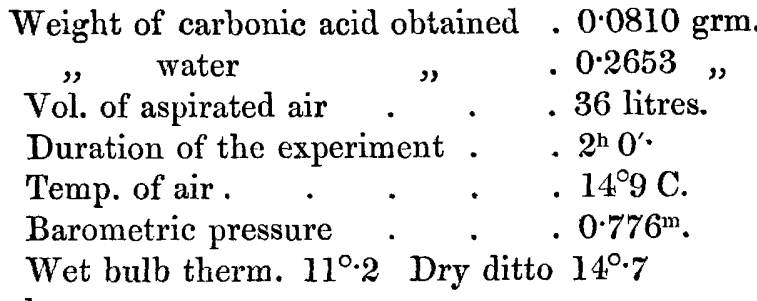

Hence we have :

Vol. of carbonic acid at $0^{\circ} \& 0.76 \quad 40.77$ cub. cent. air. . . . 34.29 litres. or in 10,000 volumes of air 11.89 vols. of carbonic acid.

The quantity of aqueous vapour found was $7 \cdot 74$ grms. per cubic metre; the thermometrical observations giving $8.3 \mathrm{grms}$. per cubic metre

From this determination it is seen that under like conditions the quantity of carbonic acid, and consequently the amount of ventilation remains constant on two consecutive nights.

\section{Experiment VI.}

In order to determine the increase in the carbonic acid produced by a crowded state of the room, 4 additional men slept in the room, on another occasion, making a total of 20 men, and the carbonic acid was estimated as before. The presence of a trace of carhonic oxide or hydro-carbons was also detected by passing the air, deprived of moisture and carbonic acid, over ignited oxide of copper, and collecting the carbonic acid and water formed. The other conditions, as to stoppage of artificial ventilation, \&c. \&c., remained the same as in Experiment IV. 
Weight of carbonic acid obtained . . 0.0801 grm. Weight of $\mathrm{CO}^{2} \& \mathrm{HO}$ from $\mathrm{CO} \& \mathrm{C}^{n} \mathrm{H}^{\mathrm{n}}$. 0.0102 " Volume of aspirated air . . . . 30 litres.

Temp. of air $12^{\circ} 5 \mathrm{C}$. Barometric pressure $0 \cdot 764^{\mathrm{m}}$ Wet bulb thermometer $8^{\circ} 4$. Dry ditto $11^{\circ} 7$

\section{Hence :}

Vol. of carbonic acid at $0^{\circ} \& 0 \cdot 76 \quad . \quad 40 \cdot 32$ cub. cent. , air . . . . 28.43 litres.

or in 10,000 volumes air $14 \cdot 18$ vols. carbonic acid.

The volume of carbonic oxide and marsh gas corresponding to the volume of water and carbonic acid obtained is found to be about 1 part in 10,000 .

The most important conclusions which we may draw from these determinations are, that even in cold weather, an insufficient ventilation is obtained in the soldiers' sleeping rooms by means of accidental sources of fresh air, and of the chimney draught occasioned by a small fire. In the summer when the difference between the temperature of the outer and the inclosed air becomes very small, the ventilation by chimneys and windows alone will become more inefficient.

In order to determine how far the natural or accidental sources of ventilation supply the necessary exchange of air, in cases in which the production of carbonic acid is more rapid, several determinations were made in crowded school-rooms in which the direct access of fresh air was more or less checked.

\section{Experiment VII.}

Large day-school for boys. Capacity of room 22,140 cub. $\mathrm{ft}$. Number of boys present 164 . Imperfect ventilation from stoveflue, and accidental sources. Determination made after the room had been occupied for $2 \frac{1}{2}$ hours.

Weight of carbonic acid obtained . $\quad .0 .0519 \mathrm{grm}$.

Vol. of aspirated air . . . . 12 litres.

Temp. of air $18^{\circ} \mathrm{C}$. Barometric pressure $0.759^{\mathrm{m}}$

Wet bulb therm. $16^{\circ} 7$. Dry ditto . $19^{\circ} 1$

Hence :

Vol. of carbonic acid at $0^{\circ} \& 0 \cdot 76 \quad .26 \cdot 12$ cub. cent.

, air. . . . . . 11.01 litres.

or in 10,000 volumes of air $23 \cdot 71$ volumes of carbonic acid. This corresponds to an allowance of 330 cubic feet of air per head per 
hour (calculated as in Experiment IV) or less than 6 cubic feet per minute.

The aqueous vapour amounted to 12 grms. per cubic metre or $75 \cdot 0$ per cent. on the saturating quantity.

\section{Experiment VIII.}

The carbonic acid contained in the atmosphere of a crowded school-room, having a capacity of 4,640 cubic feet, and containing 67 boys, was next determined. The only means of exchange of air consisted in a chimney draught and accidental openings from windows, doors, \&cc.

Weight of carbonic acid obtained . . $0.0687 \mathrm{grm}$.

Volume of aspirated air . . . . 12 litres.

Temp. of air $12^{\circ} \mathrm{C}$. Barometric pressure $0.7478^{\mathrm{m}}$

Wet bulb therm. $10^{\circ} 6$. Dry ditto $12^{\circ} 4 \mathrm{C}$.

\section{Hence :}

Volume of carbonic acid at $0^{\circ} \& 0.76$. 34.57 cub. cent. air. . . . $11 \cdot 15$ litres.

or 10,000 volumes air contain 31.00 vols. of carbonic acid. This represents an amount of ventilation of 240 cubic feet per head per hour, or only 4 cubic feet per minute.

Hence it is seen that the accidental sources of ventilation are quite inadequate to furnish the requisite amount of exchange of air in the case of crowded schools.

The next point to which I directed my attention was the distribution of carbonic acid throughout inhabited spaces, ventilated by a chimney draught together with windows, doors, \&c.

It has been stated that in common, unventilated $d w e l l i n g-r o o m s$, the heated carbonic acid formed by respiration, and combustion of illuminating substances, on ascending accumulates in the upper parts of such rooms, not being removed by the current of fresh air entering by the doors and windows, and issuing by the fire-place into the chimney. A permanent atmosphere rich in carbonic acid is thus supposed to exist in all inhabited rooms, not artificially ventilated at top, and persons breathing the air above the level of the chimney opening were conceived to be respiring an unhealthy air, whilst children breathing below that level, were asserted to be consuming a healthy air, free from any excessive quantity of carbonic acid. 
This supposition is rendered extremely doubtful by two purely theoretical considerations.

1. The known laws of expansion of gases by heat.

2. The known laws of the diffusion of gases.

Experiment, both chemical and physical, has most fully confirmed this theoretical presumption, and has proved that in ordinary dwelling-rooms, even in the exaggerated form of crowded school-rooms, the above causes are quite sufficient to equalize, throughout the closed space, the amount of carbonic acid formed by respiration; that in fact the atmospheres of such inclosed spaces are homogeneous as regards the contained carbonic acid.

A series of valuable observations made on the direction and force of the currents in the atmosphere of a heated room has been lately made for the Commission on Warming and Ventilating Private Dwellings, by Mr. J. F. Campbell, the Assistant Secretary of the Board of Health. Mr. Campbell determined the effects produced on the atmosphere of a closed room by the radiant heat from a fire, by means of thin filaments of floss-silk placed in regular position, throughout the space to be examined. The observations thus conducted, show, that a continual and rapid circulation of the air takes place throughout the inclosed space; the rarified atmosphere in front of the fire rising rapidly, with a force of from 14 to 30 grains per square foot, as measured by Mr. Campbell, and spreading out along the ceiling in the direction of the cooling surfaces of the walls and windows, where it immediately falls, and is carried again forward to the fire to supply the place of the expanded air rising to the ceiling.

In order to obtain chemical evidence regarding the homogeneous nature of the inclosed atmosphere, simultaneous carbonic acid determinations were made in the air collected above and below the level of the chimney opening in several unventilated rooms.

\section{Experiment IX.}

The first simultaneous carbonic acid determination in the air of two different parts of a closed unventilated space, was made in a small room inhabited by a costermonger's family.

Capacity of room 950 cub. ft., containing 9 persons. Chimney draught from small fire, together with accidental sources the only means of ventilation. 
A.-Air collected 6 inches from ceiling in centre of room.

Weight of carbonic acid obtained . . 0.0266 grm.

Vol. of aspirated air . . . . 12 litres.

Temp. of air $16^{\circ} \mathrm{C}$. Barometric pressure $0.7425^{\mathrm{m}}$

Hence we have :

Vol. of carbonic acid at $0^{\circ} \& 0.76 \quad$. 14.09 cub. cent. air . . . . 11.03 litres.

or in 10,000 vols. air $12 \cdot 13$ vols. carbonic acid.

B.-Air collected $2 \frac{1}{2}$ feet from floor below level of the opening of chimney-flue.

Weight of carbonic acid obtained . . 0.0280 grm.

Vol. of aspirated air . . . . 12 litres.

Temp. of air $16^{\circ}$. Barometric pressure. $0 \cdot 7425^{\mathrm{m}}$

\section{Hence :}

Vol. of carbonic acid at $0^{\circ} \& 0.76 \quad$. 14.09 cub. cent. air. . . . . . 11.03

or in 10,000 vols. of air $12 \cdot 76$ vols. carbonic acid.

Experiment X.

Crowded school-room. Capacity 4640 cubic feet. Number of boys 70. Temperature of air $14^{\circ} 5$. Barometric pressure $07427^{\mathrm{m}}$. Ventilation from chimney flue and accidental openings.

A.-Air collected 6 inches from ceiling.

Weight of carbonic acid obtained

Vol. of aspirated air . .

. $0.0719 \mathrm{grm}$.

- 12 litres.

Hence :

Vol. of carbonic acid at $0^{\circ} \& 0 \cdot 76$ air . or, in 10,000 vols. air 33.05 carbonic acid.

- $36 \cdot 19$ cub. cent. - 10.95 litres.

B.-Air collected 3 feet from floor-below level of chimney-piece -at level of boys' heads when sitting.

Weight of carbonic acid obtained

Vol. of aspirated air
- $0.0708 \mathrm{grm}$.

. 12 litres.

\section{Hence :}

Vol. of carbonic acid at $0^{\circ} \& 0 \cdot 76 \quad$. $35 \cdot 63 \mathrm{cub}$. cent. air . . . 10.95 litres.

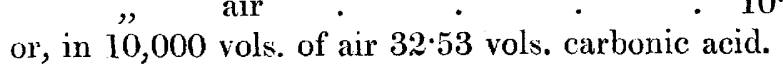




\section{Expeniment XI.}

A second determination in the same locality, under similar circumstances.

Temperature of air $12^{\circ} 5$. Barometric pressure $0.7627^{\mathrm{m}}$. A.-Collected, 6 inches from ceiling.

Weight of carbonic acid obtained . $0.0539 \mathrm{grm}$.

Vol. of aspirated air . . . . 12 litres.

Hence we have:

Vol. of carbonic acid at $0^{\circ} \& 0.76 \quad . \quad 27 \cdot 12$ cub. cent. , air . . . . . 11.35 litres. or, in 10,000 air, 23.9 volumes of carbonic acid. B.-Collected, $2 \frac{1}{2}$ feet from floor.

Weight of carbonic acid obtained $\quad 0.0555 \mathrm{grm}$.

Vol. of aspirated air . . . . 12 litres.

\section{Hence :}

Vol. of carbonic acid at $0^{\circ} \& 7 \cdot 76 \quad$. $27 \cdot 93 \mathrm{cub}$. cent. or, in 10,000 vols. air 24.59 vols. carbonic acid.

\section{Experiment XII.}

Simultaneous carbonic acid determinations made in a large and more crowded school-room (for dimerisions, \&c. see Expt. VII.)

Temperature of air $15^{\circ}$. Barometric pressure $0.7485^{\mathrm{m}}$. A.-Air collected, 6 inches from ceiling.

Weight of carbonic acid obtained . . 0.0590 grm.

Vol. of aspirated air . . . . 12 litres.

\section{Hence:}

Vol. of carbonic acid at $0^{\circ} \& 0 \cdot 76 \quad$. $29 \cdot 69$ cub. cent.

$$
\text { air . . . . } 11.01 \text { litres. }
$$

or in 10,000 vols. air 26.96 vols. carbonic acid.

B.-Air collected 3 feet from floor.

Weight of carbonic acid obtained

Vol. of aspirated air

Hence :

Vol. of carbonic acid at $0^{\circ} \& 0.76$ air or in 10,000 air $29 \cdot 49$ vols. carbonic acid.
. $0.0645 \mathrm{grm}$.

. 12 litres.

- $32 \cdot 46$ cub. cent.

. 11.01 litres. 


\section{Experiment XIII.}

Simultaneous carbonic acid determinations made at the Wellington Barracks. Room of similar dimensions as in previous experiments. Supplied with Arnott's stove and ventilator; both flue and ventilator fully open. Fire nearly out, $20 \mathrm{men}$ in room. Other conditions as before.

Atmospheric temperature $16^{\circ} 0$. Barometric pres. $0 \cdot 7640^{\mathrm{m}}$. A.-Air collected 3 inches from ceiling.

Weight of carbonic acid obtained

Vol. of aspirated air

- 0.0308 grm.

. 12 litres.

\section{Hence :}

Vol. of carbonic acid at $0^{\circ} \& 0.76 \quad$. $15.50 \mathrm{cub}$. cent.

or in 10,000 vols. air 13.82 vols. carbonic acid.

. $11 \cdot 20$ litres.

B.-Air collected $2 \frac{1}{2}$ feet from floor.

Weight of carbonic acid obtained $\quad 0.0375 \mathrm{grm}$.

Vol. of aspirated air . . . 12 litres.

\section{Hence :}

Vol. of carbonic acid at $0^{\circ} \& 0.76 \quad$. $18.87 \mathrm{cub}$. cent. air. . . . . 11.20 litres.

or in 10,000 vols. air 16.84 vols. carbonic acid.

From these determinations it is seen that in inhabited dwellingrooms or school-rooms, the carbonic acid is distributed equally throughout the atmosphere, the small differences arising not only from the errors of experiment, but also from the slightly varying composition of the currents of air passing over the point at which the air was collected.

In order to determine the influence which a considerable elevation of temperature, from the combustion of large quantities of gas and the respiration of a number of persons, exerted upon the distribution of carbonic acid, two simultaneous determinations were made in the air from the pit and gallery of a fashionable crowded theatre.

\section{Experiment XIV.}

By means of a system of tubes, the air was collected at a height of 4 feet above the stage over the stalls, and also at a distance of 30 feet directly above the first position in the front of the gallery. 
Temperature of the air $23^{\circ}$ C. Barometric pressure $0.7376^{\mathrm{m}}$. A.-Air collected 34 feet above stage.

Weight of carbonic acid obtained . 0.0444 grm.

Vol. of air aspirated . . . 8 litres.

\section{Hence :}

Vol. of carbonic acid at $0^{\circ} \& 0 \cdot 76 \quad$. 22.34 cub. cent.

" air . . . . 6.96 litres.

or in 10,000 volumes of air $32 \cdot 12$ vols. carbonic acid.

B.-Air collected 4 feet above the stage

Weight of carbonic acid obtained

Vol. of aspirated air . .

. $0.0547 \mathrm{grm}$.

- 12 litres

\section{Hence :}

Vol. of carbonic acid at $0^{\circ} \& 0 \cdot 76 \quad$. $27.53 \mathrm{cub}$. cent.

" air . . . . 10*44 litres.

or in 10,000 volumes air 26.37 carbonic acid.

Here, as would naturally be expected, a great difference is found to exist between the amount of carbonic acid contained in the lower and in the higher layers of air.

The following tables give the results of the foregoing experiments.

TABLE I.

RESULTS OF CARBONIC ACID DETERMINATIONS IN VARIOUS

LOCALITTES.

\begin{tabular}{c|c|c|c|c|c}
\hline $\begin{array}{c}\text { Number and Locality } \\
\text { of Experiment. }\end{array}$ & $\begin{array}{c}\text { Carbonic } \\
\text { acid found } \\
\text { in } 1000 \\
\text { volumes of } \\
\text { air. }\end{array}$ & $\begin{array}{c}\text { Cubic } \\
\text { capacity } \\
\text { of closed } \\
\text { space. }\end{array}$ & $\begin{array}{c}\text { Number } \\
\text { of } \\
\text { persons } \\
\text { con- } \\
\text { tained. }\end{array}$ & $\begin{array}{c}\text { Number of } \\
\text { cubic feet } \\
\text { of air } \\
\text { per head } \\
\text { per hour. }\end{array}$ & $\begin{array}{c}\text { Amount of } \\
\text { aqueous } \\
\text { vapour } \\
\text { saturating } \\
\text { quantity = 100. }\end{array}$ \\
\hline $\begin{array}{c}\text { Experiment III. } \\
\text { Normal Air }\end{array}$ & 0.37 & - & - & - & 65.5 \\
\hline $\begin{array}{c}\text { Experiment IV. } \\
\text { Wellington Barracks }\end{array}$ & 1.242 & $\begin{array}{c}\text { cub. ft. } \\
7920\end{array}$ & 16 & $\begin{array}{c}\text { cub. ft. } \\
13 \cdot 3\end{array}$ & 66.2 \\
\hline $\begin{array}{c}\text { Experiment V. } \\
\text { Wellington Barracks }\end{array}$ & 1.189 & 7920 & 16 & $13 \cdot 0$ & 59.5 \\
\hline $\begin{array}{c}\text { Experiment VI. } \\
\text { Wellington Barracks }\end{array}$ & 1.418 & 7920 & 20 & - & 65.0 \\
\hline $\begin{array}{c}\text { Experiment VII. } \\
\text { Large School Room . }\end{array}$ & 2.371 & 22140 & 164 & 6 & 75.0 \\
\hline $\begin{array}{c}\text { Experiment VIII. } \\
\text { School Room }\end{array}$ & 3.100 & 4640 & 67 & 4 & 74.0 \\
\hline
\end{tabular}


TABLE II.

DISTRIBUTION OF CARBONIC ACID IN DWLLLING ROOMS, ETC.

\begin{tabular}{|c|c|c|c|c|c|}
\hline \multirow[b]{2}{*}{$\begin{array}{c}\text { Number and Locality } \\
\text { of Experiment. }\end{array}$} & \multicolumn{2}{|c|}{$\begin{array}{c}\text { Carbonic acid in } 1000 \\
\text { vols. air. }\end{array}$} & \multirow{2}{*}{$\begin{array}{c}\text { Deviation } \\
\text { from } \\
\text { mean. }\end{array}$} & \multirow{2}{*}{$\begin{array}{l}\text { Cubic } \\
\text { capacity } \\
\text { of room. }\end{array}$} & \multirow{2}{*}{$\begin{array}{c}\text { Number } \\
\text { of } \\
\text { persons. }\end{array}$} \\
\hline & $\begin{array}{c}\text { collected } \\
6 \text { inches } \\
\text { from } \\
\text { ceiling. }\end{array}$ & $\mid \begin{array}{c}\text { collected } \\
2 \frac{1}{2} \mathrm{ft} \text {. from } \\
\text { floor. }\end{array}$ & & & \\
\hline $\begin{array}{c}\text { Experiment IX. } \\
\text { Small Dwelling Room }\end{array}$ & $1 \cdot 213$ & 1.276 & $\begin{array}{l}- \\
+0.031\end{array}$ & 940 & $\theta$ \\
\hline $\begin{array}{c}\text { Experiment X. } \\
\text { School Room }\end{array}$ & $3 \cdot 305$ & $3 \cdot 253$ & $\begin{array}{l}+ \\
-0.016\end{array}$ & 4640 & 70 \\
\hline $\begin{array}{c}\text { Experiment XI. } \\
\text { Ditto . }\end{array}$ & $2 \cdot 390$ & $2 \cdot 459$ & $\overline{+}+0.034$ & 4640 & 70 \\
\hline $\begin{array}{l}\text { Experiment XII. } \\
\text { Larger School Room }\end{array}$ & $2 \cdot 696$ & $2 \cdot 948$ & - & 22140 & 160 \\
\hline $\begin{array}{l}\text { Experiment XIII. } \\
\text { Wellington Barracks }\end{array}$ & $1 \cdot 382$ & $1 \cdot 684$ & $\overline{+} 0.152$ & 7920 & 20 \\
\hline $\begin{array}{l}\text { Experiment XIV. } \\
\text { Crowded Theatre . }\end{array}$ & $\begin{array}{c}30 \mathrm{ft} \text {. from } \\
\text { stage } \\
3 \cdot 212\end{array}$ & $\begin{array}{l}4 \mathrm{ft} \text {. from } \\
\text { stage } \\
2 \cdot 637\end{array}$ & $\stackrel{+}{-0.287}$ & not det & mined. \\
\hline
\end{tabular}

